\title{
新幹線鉄道車両外板への超親水性酸化チタン コーティングの応用とその劣化
}

\section{森 久 史 ${ }^{1} \quad$ 伊 藤 暁 $^{2} \quad$ 辻村 太 郎 ${ }^{1}$}

\author{
1財団法人鉄道総合技術研究所材料技術研究部 \\ 2 東日本旅客鉄道株式会社新幹線総合車両センター
}

J. Japan Inst. Metals, Vol. 70, No. 8 (2006), pp. 638-641 (C) 2006 The Japan Institute of Metals

\section{Application of Super Hydrophilicity $\mathrm{TiO}_{2}$ Coating for Outer Body on Shinkansen Vehicle and Its Degradation}

Hisashi Mori ${ }^{1}$, Satoshi Ito $^{2}$ and Taro Tsujimura ${ }^{1}$

${ }^{1}$ Division of Materials Technology, Railway Technical Research Institute, Tokyo 185-8540

${ }^{2}$ Shinkansen General Rolling Stock Center, East Japan Railway Company, Rifu Miyagi 981-0112

This paper presented the results of application of super hydrophilicity $\mathrm{TiO}_{2}$ coating on Shinkansen vehicle. Also effect of metalic powder on hydrophilicity of $\mathrm{TiO}_{2}$ coatings was investigated. It was found that durability of protection from dirt adhesion was less than five months in real vehicle tests. The reason of degradation on protection was due to the contamination of metal powders produced by abrasive wear on the coating surface. Accordingly, it was considered that the degradation of hydrophilicity was attributed to the metal powder on the interface between $\mathrm{TiO}_{2}$ and water.

(Received May 2, 2006; Accepted July 4, 2006)

Keywords: Titanium oxide, photocatalyst, dirt adhesion, Sinkansen, metallic powder

\section{1. 緒言}

鉄道車両では美観維持のために出庫毎の車両清掃が行われ る. 高速環境下で走行する新幹線車両では車両の構体表面に 油状, 半固体および固体状の污れが付着し, 污れが化学的お よび物理的な力で下地塗料に強固に付着しているため, 自動 洗浄では完全に污れを落とすことが困難であり，最終的には 液性の強い洗浄剤の使用や人力に頼らざるを得ない。したが って, 車両洗浄の軽減化には, 外板塗装膜の污れ付着からの 保護および付着した污れをセルフクリーニングすることがで きる表面保護材の適用が望まれる.

酸化チタン光触媒のコーティングは, 酸化チタンの光誘起 超親水化 (水接触角が $4^{\circ}$ 以下を示す現象)を利用することに よって，コーティング表面に付着した污れのセルフクリーニ ングおよび光触媒のコーティング膜による污れ付着からの表 面保護が期待できる1). 現在, 酸化チタンの光触媒コーティ ングはビルおよび空ガラス等に適用されており，防污性に対 する有効性が確かめられている1,2).

しかし, 新幹線車両においては, 車や定置構造物に付着す る污れとは異なり, ブレーキやパンタグラフから発生する鉄 あるいは銅の金属系摩耗粉の付着がある3,4).このことか ら, 新幹線車両への光触媒コーティングの適用においては, 光触媒の超親水化に及ぼす金属摩耗粉の污れの影響等につい て検討することが必要となる. 本研究では, 酸化チタン光触
媒コーティングの実車試験を行って実車における防污性に対 する耐久性を調べた。 また, 耐久性に及ぼす金属摩耗粉の影 響を, 金属粉末模擬污れ塗布材の水接触角測定を行って基礎 的に調査した.

\section{2. 実 験 方 法}

\section{1 光触媒コーティングの実車試験}

試験には, 市販されている酸化チタン光触媒剂 STK-211 (秼石原産業製, 酸化チタン(アナターゼ型) 含有量が約 $10 \%$ ) 抢よび中間結合剂 STK-102(侏石原産業製)を用い た. 光触媒の性能に関する実車試験は, E4 系新幹線電車 (東 日本旅客鉄道( 侏保有)で行った. Fig. 1 に新幹線電車に行っ たコーティング施工部分を示す.コーティングは, 先頭車両 の肩部の片側に行った．コーティングを施工した先頭車両の 肩部は走行中の風の当たりが最も強いところであり, 污れの 付着も多い箇所である. 実車へのコーティングは, まず, 施 工面以外の部分をビニールシートでマスキングを施し, 施工 面上を脱脂面にエタノールを染久込ませて, 手作業で洗浄を 行って準備した. コーティングは, 空気圧力式の高圧スプ レー(㧣ニシヤマ製)を用い, 洗浄した施工面に中間結合剤を 被覆し, ジェットバーナを用いて $373 \mathrm{~K} \times 3600 \mathrm{~s}$ の乾燥処理 を行い, 中間結合剂のコーティング面の上から, 高圧スプ レーを用いて光触媒剤をコーティングし，ジェットバーナー を用いて $373 \mathrm{~K} \times 3600 \mathrm{~s}$ の乾燥処理を行って養生処理を行っ 


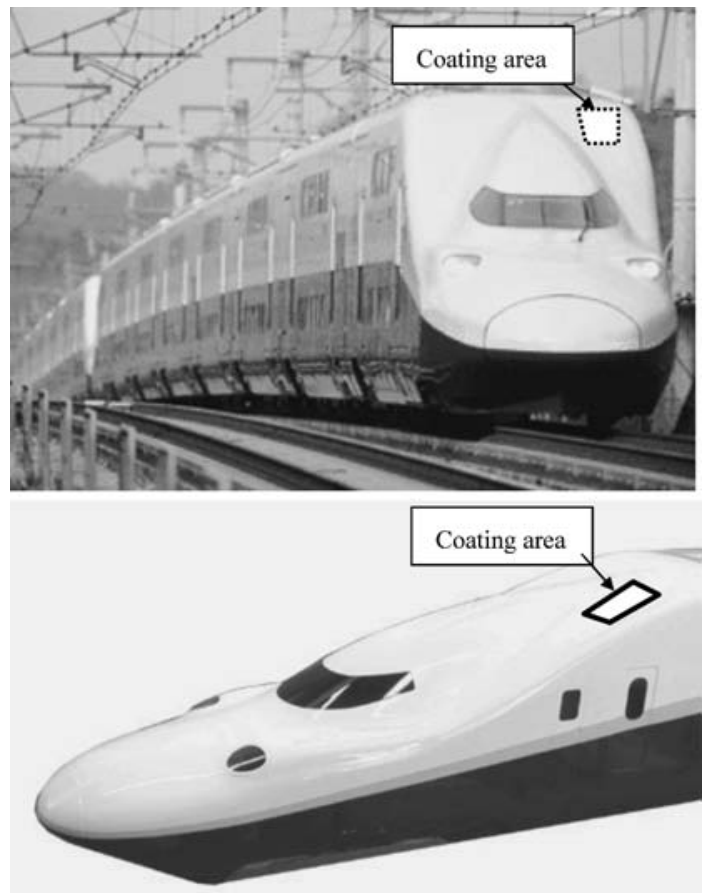

Fig. 1 Schematic view of coating area for real vehicle test of E4 type Shinkansen(East Japan Railway Company).

た、コーティングは，東日本旅客鉄道侏新幹線総合車両セン ター 交番検査車庫内で行い, コーティング時の温度は 293 $\mathrm{K}$ ，湿度は $50 \mathrm{RH} \%$ であった。

車両上のコーティング膜厚測定は, 直接測定するのが困難 であったために測定用試料を作成して間接的に行った．膜厚 測定用の試料は， $500 \mathrm{~mm} \times 100 \mathrm{~mm} \times 100 \mathrm{~mm}$ のアルミニウ ム合金板 (A6031)に車両用塗装(ポリウレタン樹脂)を施し， 車両所内交番検查庫内において，車両上へのコーティング施 工時に同一条件で中間結合剤抢よび光触媒剤をスプレーをし て得た。膜厚測定は膜厚測定用試料を室温で樹脂埋めし，精 密切断機で切断後, 断面に銀ぺーストを塗布して走査型電子 顕微鏡 $(5 \mathrm{kV})$ で行った。その結果，コーティング膜厚は約 5 $\mu \mathrm{m}$ であり, 車両上のコーティング膜厚は約 $5 \mu \mathrm{m}$ であるこ とを間接的に確かめている.

本研究では, 光触媒コーティングによる車両塗料への防污 性の付与を目的としているため, コーティングの性能として は, 下地塗料の明度 (JIS K5600-4) 抢よび $60^{\circ}$ 光沢 (JIS Z8741)を測定して評価した。明度抢よび光沢の測定は， コーティング養生後, 走行 1 ヶ月, 走行 3 ヶ月および 5 ヶ 月目に交番検査車庫内で行った。 また, 走行後 5 ヶ月目に はコーティング面の親水性を確認するために, 純水をスポイ ドでコーティング面上に滴下することにより，親水性の確認 を行った、コーティング膜の化学成分分析は酸素を除く化学 成分を定性的に行った，分析試料は，コーティング直後およ び走行 5 ヶ月目に扔いて採取した。試料はイソプロピルア ルコール (IPA)を含ませた脱脂綿を用いて施工面から膜と污 れを拭き取り，膜抢よび污れを含んだ脱脂面からエチルアル コールで抽出し, 大気炉内で乾燥 $(323 \mathrm{~K} \times 3.6 \mathrm{ks})$ して得 た。定性分析は EPMA を用いて行った。 EPMAの分析 は，超音波洗浄で洗浄脱脂したアルミニウム製の基板を用
い，基板上に試料を静置し，前処理を行わずに測定した。

\section{2 污れ付着の基礎試験}

基礎試験では, 実車試験で用いた光触媒剤 STK-211(侏) 石原産業製, 酸化チタン含有量 $10 \%$ ) および光触媒剤 PJC20 (JSR侏，酸化チタン含有量 $20 \%$ ) を用いた。試験片は, アルミニウム合金板 (AN01)の片面に車両用塗料(ポリウレ タン樹脂)を叙装し，塗装表面に中間結合剤 SKT-201(侏石 原産業製) 抢よび光触媒骫をコーティングして作成した，光 触媒剂抢よび中間結合剂のコーティングは高圧スプレーを用 い，室温，大気中で行った．試験の前処理としては，大気炉 内に打ける $327 \mathrm{~K} \times 1 \mathrm{~h}$ の乾燥処理と, ブラックライトを用 いた紫外線照射による光活性処理を行った。紫外線照射は照 射電圧 $0.5 \mathrm{~mW} / \mathrm{cm}^{2}$ であり，温度は $298 \mathrm{~K}$ ，湿度は $30 \% \mathrm{RH}$ で行った．コーティング膜厚は， 2.1 に示した膜厚測定方法 により調べた結果，約 $5 \mu \mathrm{m}$ であることを確かめている. 試 験は, 試験片表面のコーティング膜面に粒径 $1 \mu \mathrm{m}$ の鉄粉お よび粒径 $1 \mu \mathrm{m}$ の銅粉を約 $10 \%$ ，コーティングした表面に 直接塗布し，塗布材を財団法人鉄道総合研究所内の屋内の大 気暴露試験室において紫外線照射を行いながら 1 ケ月間の 大気暴露を行った後に数十秒毎に水接触角測定を行った.

\section{3. 実験結果および考察}

実車試験 5 ヶ月目のコーティング面の外観を Fig. 2 に示 す. 外観観察上，コーティング面には粒あるいは筋状の様々 な污れが付着しており, 塗装膜は黄色に変化した状態にあっ た．また，コーティング部分とコーティング未施工面の污れ の付着度合いは同じであり, 実車試験では施工 5 ヶ月目に 颃いて，防活性に対する効果が見られなくなった．Fig. 3 に 下地塗料の色差抢よび光沢の変化を走行時間に対して示し た．光触媒コーティングに関する基礎物性打よび構造物等へ の適用に対する性能評価方法は標準化されつつあるが，鉄道 車両への適用に対する評価方法は提示されていない1)。この ことから，コーティングを含めた車両塗料の色差打よび光沢 測定により，防污性を定量的に判断することを試みた ${ }^{3)}$ をそ の結果, Fig. 3 に示すように, 実車走行後の色差抢よび光沢 は走行時間とともに低下していることがわかる．外観観察と 合わせて色差抢よび光沢低下原因を考えると，色差抢よび光 沢の低下は，コーティング面に污れが付着しているために色 合いが初期状態から変化し，つやが喪失したためであると考 えられる，すなわち走行 5 ケ月目の段階では，防污性の機 能は有していないと考えられる.

酸化チタンコーティングによる防污性は，本来，酸化チタ ンの光誘起超親水性抢よび酸化力で得られ, 光誘起超親水性 は水接触角で定量的に評価できる5)。しかし，今回のような 実車試験に打いては, 親水性試験装置を用いて定量的に水接 触角測定を行うのは困難である，そのため，本試験では純水 をコーティング面に滴下して親水性を調べた.コーティング 膜表面に水滴を滴下させた時の水滴の状態を観察した結果が Fig. 4 である. 5 ヶ月走行後の実車でのコーティング面で は，親水性は㖪失し，すでに撥水状態にあることがわかる。 


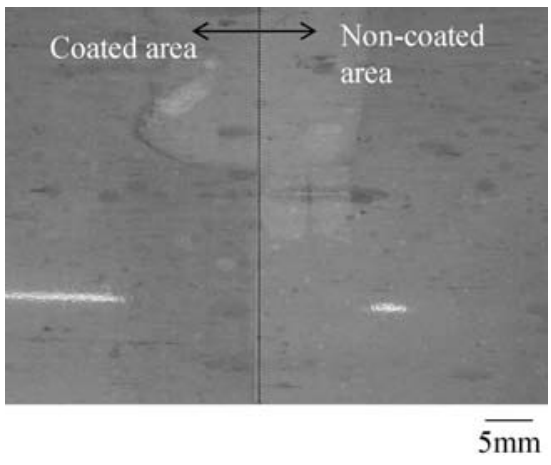

Fig. 2 Comparison of plan view on coated area and non-coated area after five months of real vehicle test.

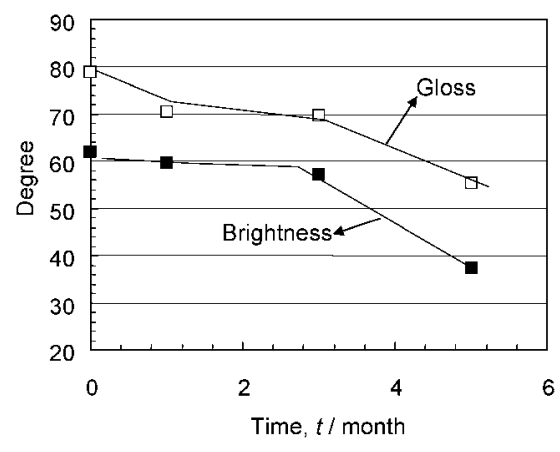

Fig. 3 Plot of gloss and brightness on coating area against running time.

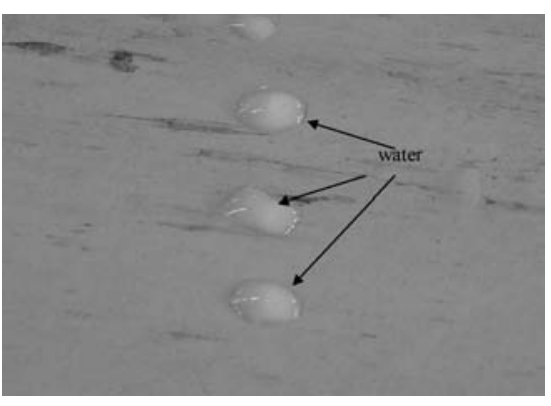

Fig. 4 Photograph of water droplet on coating area after five months of real vehicle test.
Table 1 Chemical composition of surface layer for as-coated and after 5 months on real vehicle test.

\begin{tabular}{cc}
\hline & Chemical composition \\
\hline As-coated & $\mathrm{Ti}$ \\
\hline After 5 months test & $\mathrm{Ti}, \mathrm{Al}, \mathrm{Si}, \mathrm{Mn}, \mathrm{Fe}, \mathrm{Cu}$
\end{tabular}

このことから，コーティング膜に付着した様々な污れが水へ

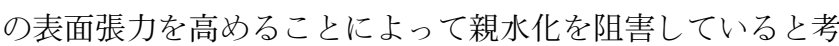
えられる.コーティングの親水化を阻害している污れの種類 を調べるために，酸素を除く化学成分の定性分析結果を Table 1 に示す.

コーティング施工直後と走行後 5 ヶ月目に打ける成分比 較するが，コーティング施工直後では，酸化チタンの主成分 であるチタン $(\mathrm{Ti})$ のみか検出されない。しかし, 走行後 5 ヶ月目の車両から抽出した成分には，鉄 $(\mathrm{Fe})$ や銅 $(\mathrm{Cu})$, シ リコン $(\mathrm{Si})$ が検出されている.

酸化チタン以外で検出された，金属成分である鉄抢よび銅 は，トロリ線(銅線)抢よび集電装置(パンタグラフ)用焼結す り板 (焼結鉄合金)の主な化学成分である4 線と摩擦しながら集電することから，すり板およびトロリ線 の成分である鉄や銅を含む金属系摩耗粉は車両上方から飛来 して車両上方に付着する.コーティング部分は Fig. 1 に示 すように，車両の肩部分であり，摩耗粉が最も堆積しやすい 部分である、コーティングを行った車両肩部の外観を観察す ると, Fig. 2 に示すように全体的に黄色に変色し，堆積した 金属粉が酸化した状態にあると考えられる，このことから， 金属摩耗粉がコーティングの光誘起親水性に影響を及ぼして いると考えられる。

そこで，コーティングに鉄抢よび銅の金属粉を塗布して暴 露試験を行い，水接触角を測定して超親水性に及ぼす金属粉 の影響を調べた．Fig. 5 に光触媒剤のみをコーティングした 暴露試験片で測定した水接触角の変化を示す．光触媒剤のみ のコーティング材では超親水性を示す接触角まで水接触角は 低下する. Fig. 6 に光触媒剤に鉄粉を塗布して暴露試験を行 った試験片で接触角の時間変化を調べた結果を示す。接触角

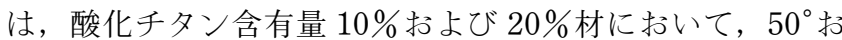

よび $30^{\circ}$ で飽和するようになり，接触角 $4^{\circ}$ 以下までは低下し なかった．これらのことから，鉄粉付着が酸化チタン光触媒 コーティング材の光誘起超親水性に影響を及ぼしていること がわかる5)。また，銅粉について見ると，Fig. 7 に示すよう に接触角の時間変化は，鉄の場合とは異なって飽和せずに親 水化する傾向が見られる．しかし，銅の場合，親水化時間は Fig. 6 に示した未塗布暴露材に比較すると 3 倍程度要するよ うになる。このことから，鉄とは程度が異なるが，銅の付着 も親水化に影響を及ぼすことがわかる．鉄と銅で見られた相 違は，鉄と銅の酸化チタンのバンドギャップに対する影響や 酸化の自由エネルギーの相違異などが原因であると考えられ るが，今後検討を要する5,6).

鉄や銅などが付着すると接触角が変化した．ここで親水化 の指標となる接触角は，固体表面のぬれ特性を定量的に表す ものである．固体表面のマクロなぬれ特性は，式（1）に示 す, ヤング・デュプレの式で表すことができる7).

$$
W_{\mathrm{A}}=\gamma_{\mathrm{LG}}(1+\cos \theta)
$$

ここで， $W_{\mathrm{A}}$ は固液界面形成に伴う界面自由エネルギー, $\gamma_{\mathrm{LG}}$ は表面自由エネルギー， $\theta$ は固体一液体界面の接触角であ る. 酸化チタン光触媒の光誘起親水性において, ぬれ性の向 上，すなわち，親水性は， $\mathrm{OH}$ 基の増加，ガス吸着分子の分 極抢よびガス吸着層の減少が支配的であることが考察されて いる77)。ところが，本試験で見られた実車結果や基礎試験の 場合の，鉄や銅などの金属粉が付着する場合にはガス分子よ りも金属粉の吸着の影響が大きいと考えられる．酸化チタン に鉄イオンが吸着すると鉄イオンが光触媒間の電子授受剤と して働きより強い酸化力を持つ反応が生じることが知られて いる8)．有機物の場合であれば，酸化分解するが，本研究の 場合のような金属粉付着においては，金属自体が酸化チタン の強い酸化力で酸化するようになり膜内に残留するようにな る. その結果，界面自由エネルギーが変化して接触角が低下 しなくなる，すなわち，親水化が得られなくなると考えられ る.このことから，付着した金属粉が酸化して親水性に影響 すると考えられる。

\section{4. 結 論}

本研究では, 酸化チタン光触媒コーティングの超親水性に 及ぼす影響因子を実車試験並びに基礎試験を行って検討した 


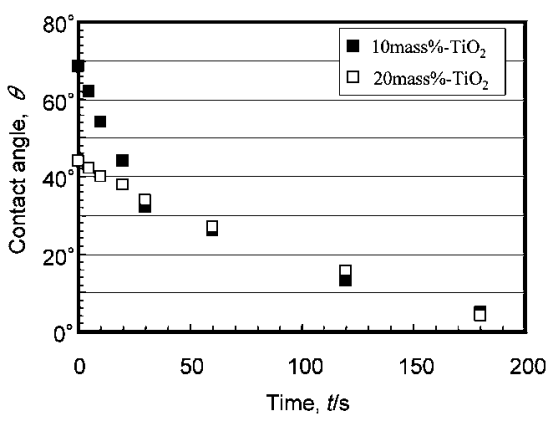

Fig. 5 Plot of contact angle against illumination time.

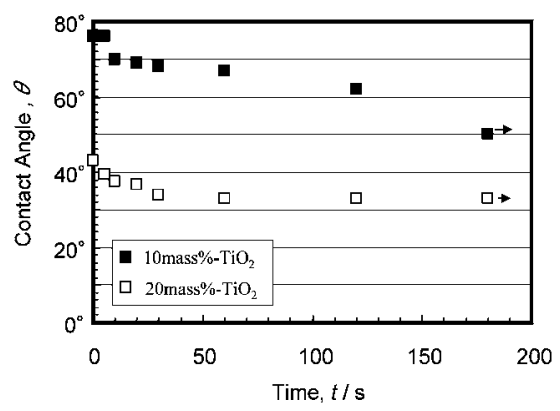

Fig. 6 Plot of contact angle of $\mathrm{TiO}_{2}$ coating with $\mathrm{Fe}$ powders against illumination time.

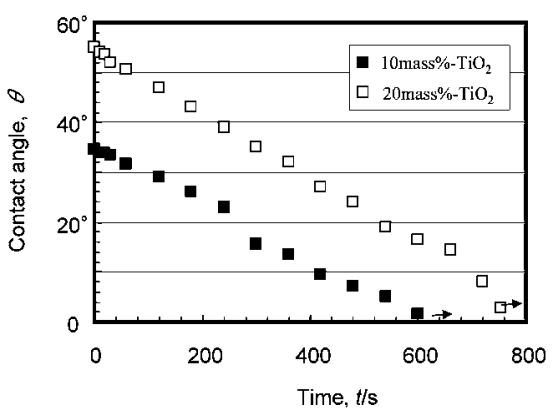

Fig. 7 Plot of contact angle of $\mathrm{TiO}_{2}$ coating with $\mathrm{Cu}$ powders against illumination time.
結果を報告した．実車試験の結果，コーティング 5 ヶ月目 に抢いてコーティング表層に污れが残留するようになり，色 差および光沢は低下し，親水性はすでに有していない状態に あった，性能を低下させた原因としては，鉄道車両独特の污 れである，集電装置のすり摺板やトロリ線の鉄および銅の金 属摩耗粉であった．模擬污れ試験を行った結果によると鉄お よび銅は，親水化に影響することが確証された．この原因と して, 塗装膜に取りこまれた金属粉は, 自己酸化して酸化物 として残留し，酸化チタンと水との界面エネルギーに影響を 及ぼすと考えられる。
文献

1) A. Fujisima, K. Hashimoto and T. Watanabe: Hikarisyokubai no Shikumi, (Nippon Jitsugyo Syuppansha, 2000) pp. 16-23.

2) A. Fujishima, K. Hashimoto and T. Wanatabe: $\mathrm{TiO}_{2} \mathrm{PHO}-$ TOCATALYSIS Fundamentals and Applications, (BKC, Inc, Tokyo, Japan, 1999) pp. 46-64.

3) F. Horie: Rolling Stok and Technology 77 (2002) pp. 2-7.

4) M. Tanaka, T. Kimura, T. Enari and S. Endo: Research data in Railway Technical Research Institute, No. Q54622-01 (1995) pp. 6-18.

5) A. Nakajima: Kinzoku 75(2005) pp. 214-221.

6) Japan Inst. Metals: Kinzoku Data Book, (Maruzen, 1974) pp. 8181.

7) T. Kobayashi, K. Oguri, M. Iwase and Y. Nishi: J. Japan Inst. Metals 69(2005) 1026-1030.

8) R. Konta, H. Kato, H. Kobayashi and A. Kudo: Phys, Chem. Phys. 5(2003) 3061-3065. 